\title{
Combating Financial Crimes Through Forensic Accounting in Nigerian Public Sector
}

\author{
A. A. Olaoye \\ Bsc (Ed), (Acct), Msc (Acct) \& ACA \\ Doctoral Student, School of Post Graduate Studies, Faculty of Management Sciences, Department of \\ Accounting, Ekiti State University, Ado-Ekiti, Nigeria \\ Prof. G. T. Akinleye \\ Senior Lecturer, Department of Accounting, Ekiti state University, Nigeria
}

\begin{abstract}
Financial crimes are a global issue which remains unresolved. These crimes have plagued every corner of the world economy. The adverse effect of these crimes is immense in Nigeria. Continuous research confirmed a strong demand for the forensic accounting of preventing, detecting and arresting of financial crimes menace in Nigeria and the rest of the world. However, the studies of combating financial crimes through forensic accounting are very few in literature and not fully explored in Nigerian public sector. This study therefore, sets to examine the impact of forensic accounting techniques for combating financial crimes in Nigerian public sector. This study employs a survey research design and purposive sampling technique to select the sample of eighty six (86) accountants and auditors of the three selected ministries in Osun State, Nigeria. Both primary and secondary data were collected. The primary data was collected through a designed structured questionnaire. The data collected was analyzed using descriptive and inferential statistical tools. It was found that combating of financial crimes in Nigerian public sector through the application of forensic accounting is possible as the. $\mathrm{p}$-value $=0.00<0.01$. This study therefore concluded that, government of Nigeria should increase the interest in and facilitate the growth of forensic accounting by giving legal backing for proper monitory and investigation of alleged cases of financial crimes. This study recommended that, all government ministries, agencies and parastatals should establish forensic accounting unit to help strengthen internal controls and ensure thorough investigation in order to prevent, deter and detect financial crimes and the University regulatory body as well as the accounting professional bodies should ensure that forensic accounting courses are included in the curricula to ensure the training and increased awareness of forensic accounting in Nigeria.
\end{abstract}

Keywords: Forensic Accounting, Financial Crimes, Nigerian Public Sector.

DOI: $10.7176 /$ RJFA/11-11-05

Publication date:June 30th 2020

\section{Introduction}

The rise in financial crimes at the beginning of the twenty-first century was associated with increased financial crisis incidence and awareness, thereby questioning the role of forensic accountants on their prevention and detection (Ezejiofor, Nwakobu \& Okoye, 2016). Oyeokun (2017) affirms that corruption and other financial and economic crimes are the bane of Nigerian development efforts and harm the economy but the perceived lack of the appropriate litigation support services in the court is a principal cause of misjudgment. Continuous research confirmed a high demand of the prevention and uncovering of these crimes by institutions and nations as a response to closer scrutiny of the financial activities of government ministries and agencies (Evans, 2017). Financial crimes (FCs) committed by individuals and organizations include fraud of any kind, money laundering, embezzlement, bribery, extortion, corruptions and tax evasion (Izedonmi \& Ibadin, 2012). Most of these financial crimes are difficult to detect, through the statutory audits and most of those detected are not reported for fear of bad publicity (Dada, Enyi \& Owolabi, 2013).

Forensic Accounting emerged in response to the high incidence of frauds (Ugwuja, 2016). The origin of forensic accounting could be traced back to 1800s but was coined in 1946 by Peloubet (Abuh \& Adio, 2018). Forensic accounting comprises investigation, litigation support and dispute resolution and the upsurge in financial crimes in countries and the world as a whole accentuated the need for the application of its techniques (Dada, et al. 2013) Forensic accounting is gaining dominance in fighting against fraud and other financial crimes (Adeniyi, 2016). However, some of these financial crimes are difficult to detect, through the statutory audits and most of those detected are not reported for fear of bad publicity (Dada, Enyi et al., 2013). Statutory auditing may uncover some financial crimes, but detailed disclosure of these crimes and their prosecution demand special techniques and forensic accounting application is perceived to provide these techniques (Naziru \& Aidi, 2018). Forensic accounting is capable of bridging statutory audit expectation gap relating to fraud prevention, detection, and prosecution of financial crime (Rabiu, Noorhayati \& Muhammad, 2015). The use of forensic accounting techniques could better enhance the prosecution of financial crime cases than the statutory auditing (Evans, 2017). 
A review of the literature on financial crimes disclosed that these crimes are growing problems that have an impact on the world's economies (Raymond, Nkiru, Jane \& Okoye, 2016). Recently, the Federal Bureau of Investigation of United States of America estimated that more than three hundred billion dollars $(\$ 300)$ is loss annually to fraud and many of these crimes are difficult to identify due to the concealment of the perpetrators' activities (Evans, 2017). FCs was also attributed to the collapse of Enron, WorldCom, Tyco, Adelphia, to corporate fraud where $\$ 460$ billion was said to have been lost. More so, Cadbury Nig Plc whose books were criminally manipulated by management was credited to have lost $\$ 15$ million in Nigeria (Ezejiofor et al., 2016). In response to these financial crimes, many countries have championed the fight against them in the history of the whole world. The American Institute of Certified Public Accountants (AICPA) suggested that more forensic accounting techniques and procedures should be incorporated in the detection of financial reporting since auditors and forensic accountants have different training, skills and mindsets (Evans, 2017).

This study covers three selected ministries in Osun State, Nigeria. However, the studies of combating financial crimes through forensic accounting are very few in literature and not fully explored in the Nigerian public sector. It is against these gaps that this study set out to examining the impact of forensic accounting on combating financial crimes in Nigerian public sector. Specifically, this study seeks to determine the impact of forensic accounting techniques (FATs) such as interviewing and interrogation, business intelligence, data mining and financial ratio analysis as mechanisms for combating financial crimes in Nigeria public sector. Findings from this study would be of great value to policy makers and Nigerian government as it would create more awareness to anti-corruption agencies, accounting practitioners, accounting lectures and students, future researchers, and indeed the general public on the impact of forensic accounting in combating financial crimes at a time like this, when the country is deeply soaked in and characterized by corruption, frauds and other financial crimes that remain the worst enemy to Nigerian economy.

\section{Conceptual Review}

\subsection{Forensic Accounting}

The term" forensic accounting" was coined in 1946 by Peloubet but had been in existence as far back as 1800s (Evans, 2017). Forensic accounting is also known as investigative accounting, fraud audit and even judicial accounting (Nenyiaba, Osisioma \& Okoye, 2015). Forensic accounting is the unification of accounting, auditing, investigation, and law (Mohammed \& Peter, 2016). Forensic accounting is the examination and interpretation of legal facts and evidence, and expert witnessing in the court of law (Tim \& Sam, 2016). Forensic accounting is a specialized accounting field which makes use of auditing and with investigative skills to assist in legal matters that arises from activities of current and potential disputes or litigation (Manas, 2014). Forensic accounting is an aspect of accounting that is suitable for a higher level of assurance for law courts (Akenbor \& Ironkwe, 2014). Forensic accounting is a generally accepted accounting, auditing principles, and accounting expertise to establish losses or gains, property, damages, the effectiveness of internal controls and frauds for the legal system usage regarding criminal and civil disputes (Anuolam, Onyema \& Ekeke, 2016; Olaoye, Ogundipe \& Dada, 2019).

Forensic accounting practice began in 1817 , where a decision of a court on bankruptcy was based on the testimony of an accountant (Evans, 2017). A Scottish accountant used his knowledge and expertise through opinion to support arbitration proceedings in the 1820s (Eze \& Okoye, 2019). The term "Forensic accounting" was used by Kautilya who stated several means of embezzlement in 1946 (Ehigbiren, 2016). In a nutshell, forensic accounting is the accounting spoken in the language of the law. It is a specialized area of accounting practices that employs accounting, auditing, investigation and legal skills and knowledge to provide evidence of information suitable or relevant to legal issues.

\subsubsection{Forensic Accounting Techniques \\ 2.1.2 Business Intelligence}

Business intelligent technique is the intelligence used to conduct financial investigations, prepare evidence for the purpose of law enforcement and the prosecution of the offenders (Faboyede, Makoro \& Ben-Caleb, 2013). Quite recently the corporate world has adopted the use of, business intelligence to directly investigate an employee being suspected to be involved in illicit business activities (ACFE, 2013; Jephitha Gillian \& George, 2019). Surveillance can provide financial investigators with a wealth of general information in order to combat FCs by physically follow and observe the subject while remaining undetected (Gbegi \& Adebisi, 2013; Aduwo, 2016). Forensic firms normally subscribe to various public databases to gather business intelligence through the database on individuals and companies; that can assist the forensic accountants to obtain the intelligent information in South Africa (Benjamin, 2012). Through the trash collection, people routinely discard papers, receipts, credit card slips, bank statements, cancelled cheques, repair bills, tax assessment records, correspondence and other personal items that while alone are meaningless, when considered together can offer a detailed picture of the suspect's activities (Ezejiofor et al., 2016).

\subsubsection{Forensic Analytics}

Forensic analytics contains some techniques like Data mining, ratio analysis and many others. Data mining (DM) 
derives its name from searching for information in a large database. DM has to do with the ability of the researcher to search and analyze data in order to find the implicit but potentially useful information which has been buried due to the passage of time on the gigabytes of the system (Dickson, Ogijo \& Samuel, 2013).It is useful in an exploratory analysis, where there is no predetermined interest outcome (Glenn \& Matthew, 2004). DM uses a board family of computational methods which are statistical analysis, decision trees, neural network, rule induction and refinement, and graphic visualization (Ezejiofor et al., 2016).

The accountants use ratio analysis (RA) is computed to determine how well the firm is doing in the current year over the previous years (Ibrahim, Adeyemi \& Odunayo, 2015). RA could also be employed in the same way to check on the financial health of the company when it has to do with fraud because it will serve as a pointer to waste, abuse and fraud (Ibrahim, Rose \& Mohammed, 2016). RA can identify fraud by computing the variance in a set of transactions and then calculates the ratios for the selected numeric field (Igweonyia, 2016). If the result of ratio of the highest value to the lowest value that is maximum / minimum is close to 1, the forensic accountant will know that there is no much doctoring of the result. This implies that there is no much variance between the highest and the lowest prices. But if the ratio is large, this is an indication that too much was paid for the product than required which indicates the possibility of fraud (Ezejiofor et al., 2016).

\subsubsection{Financial Crimes}

Financial crimes (FCs) on the other hand, have been variously described in literature. Wikimedia dictionary defines FCs as crimes involving the unlawful conversion of property belonging to another to one's own (Evans, 2017). The financial crimes (EFCs) as described in the Economic and Financial Crimes Commission's Act of 2004 in Nigeria is the "violent, criminal and illicit activities committed with the objective of earning wealth illegally in a manner that violates existing legislation" (Izedonmi, 2012). FCs are usually committed by individuals and organizations include corruptions, money laundering, embezzlement, bribery, extortion, tax evasion, fraud of any kind, illegal oil bunkering, illegal mining, artificial pricing, theft of intellectual property and piracy, foreign exchange malpractice including counterfeiting, currency (Izedonmi et al., 2012; Anuolam et al., 2016; Ameka \& Ikhatua, 2016 \& Evans, 2017).

Corruption is the most popular form of financial crime. Corruption by public officials (Political corruption) is tantamount to stealing from the poor. Corruption may appear in form of corruption fraud which includes conflicts of interest, bribery, and extortion (Anuolam et al., 2016 \& Evans, 2017). Bribery is a situation whereby money or something else of value is offered in order to influence a situation or person (Dada et al., 2013). Extortion is the opposite of bribery, and happens when money is demanded rather than offered in order to secure a particular outcome (Dada et al., 2013). The fraudsters use conflict of interest fraud to exert their influence to achieve a personal gain which detrimentally affects the company (Lawan, Magaji \& Naziru, 2018). The fraudster may not benefit financially, but rather receives an undisclosed personal benefit as a result of the situation (Egbunike \& Amakor, 2013).

Money laundering represents the illegal flow of funds across the borders. The Money Laundering Prohibition Act of 2004 of Nigeria provides that no person or corporation or organisation is allowed to make or accept cash payments of a sum in excess of N500,000.00 or its equivalent in the case of an individual, and N2,000,000.00 or its equivalent in the case of a corporation, unless such cash payment or acceptance is undertaken through a financial institution. Also, a transfer of funds or securities to or from a foreign country in excess of US\$10,000 or its naira equivalent must be reported to the Central Bank of Nigeria (CBN) or the Securities and Exchange Commission $(\mathrm{SEC} \|)$ in the case of a public corporation (Ijeoma, 2015).

Embezzlement is another type of FCs (Evans 2017). Embezzlement is improperly taking money from someone to whom you owe some type of duty (Ehiogbiren \& Atu, 2016). The most common example is a company employee that embezzles money from his employer for example by siphoning money into account (Joseph, Okike \& Yoko, 2016). Tax evasion is also a FCs. Tax evasion is a crime through which the perpetrator attempts to avoid taxes they would otherwise owe. Tax evasion can range from simply filling tax forms with false information to illegally transferring property so as to avoid tax obligations. Individuals as well as business can commit tax evasion (Jacqui-Lyn, Constant, Jan \& Albert, 2014). Any kind of fraud is a financial crime (Izedimi et al., 2012). Ifath, Pranathi, Asra \& Amathun (2014) define fraud as the use of one's occupation for personal enrichment through deliberate misuse or misapplication of the employing organization's resources or assets. Ozili (2016) describes fraud as any act of deception performed by somebody to cheat or deceive another person to his detriment or the detriment of any other, or to cause injury or loss to another person while the perpetrator has a clear knowledge.

These frauds include misappropriation of assets, employee theft, management theft, pay roll fraud, corporate frauds, security fraud, insurance fraud, credit card fraud and some of others (Okoye \& Gbegi, 2013; Ogirili \& Appah, 2018). About employee theft, Akepe (2015) assert that cash is the favourite of fraudsters; and this accounts for about $77.8 \%$ of asset misappropriations in the U.S. According to Karen (2003), much of cash is taken by outright cash larceny and skimming .Larceny occurs when cash is taken or stolen after it has been recorded. Skimming occurs when theft of cash takes place before cash is recorded. The management thefts are committed when management over-rides the controls instituted by themselves to prevent the thefts they now commit (Okoye, 
Adeniyi \& Obidi, 2019; Okoye, Adeniyi \& James, 2019)

The financial crime of payroll fraud is usually fast tracked by a payroll clerk, internet facility or through the connivance and collusion of another staff (Yucel, 2010). Also, corporate frauds are intended to benefit the company. Categories of these frauds include financial statement fraud, anti-trust violation; securities frauds, tax evasion, false advertising, environmental crimes and the production of unsafe product (Gbegi \& Habila, 2017; Ifeanyi \& Joseph, 2018). Asset misappropriation is also a fraud. The common feature the asset misappropriation is the theft of cash or other assets from the company, for example cash theft involves the stealing of physical cash like petty cash, from the premises of a company (Ile, \& Odimmega, 2018). Obviously, financial crimes are motivated by factors such as corrupt corporate culture and conventionality. When a corrupt culture is lived and practiced every day at the workplace, this would constitute enormous pressure to financial crimes. In addition, the white-collar criminals live conventional lives. Conventionality and stability give the financial crimes the foundation of the trust. Such trust creates the opportunity to commit financial crime. Thus, conventionality and stability leads to opportunity to commit financial crime which is then rationalized (Izedomin et al., 2012; Ezejiofor et al., 2016).

\subsection{Theoretical Review \\ 2.2.1 White Collar Crimes Theory}

White collar crimes theory is attributed to Ross in 1907 that developed the concept of white collar offenses. Ross came up with the term "Crimanoloid" to refer to the person who exploits the weaknesses in society but does not fit the description of the ordinary offender. This theory was further developed by a traditional theorist Sutherland in 1938 who's his original work was published in 1949. According to Sutherland (1938), white collar crimes (WCCs) refer to as the financial crimes being carefully and intentionally organized. WCCs offenders do not consider themselves as law breakers and they do not fit the description of the ordinary criminals. Sutherland (1938) gave examples of WCCs to include occupational frauds, bribery and corruption, cybercrime, embezzlement or money laundering. Sutherland submits that WCCs are financially motivated and violence crimes involving corporate or government professionals (Evens, 2017).

Sutherland (1949) tried to connect the crime of upper white collar class with economic and business activities. Sutherland came up with an argument and preserved blue collar crimes for the poor people in the society and white collar crimes for the people of high social class and authority, claiming that poverty is not a driver of WCCs as most white collar offender is rarely poor. Sutherland further argues that the professional status in a society creates an atmosphere of both admiration and intimidation making members of the community admire the professionals and also avoid prosecuting them as they are intimidated by the professional status. This leads to less or no punishment of the white collar criminals. WCCs are complicated and less obvious than violent crimes (like blue collar crimes) as the consequences of the crimes may be shared by many people or over an extended period by the victims (Evans, 2017). Although Sutherland's definition of WCCs has generated a great deal of criticism and controversy, but it exhibits the important issue of inappropriately recognition, prevention and control of crimes perpetrated by persons in position of power. The theory of WCCs is therefore, relevant to this study as it discussed the issues relating financial crimes.

\subsection{Empirical Review}

Izedonmi et al. (2012) examined forensic accounting and financial crimes: adopting, the inference, relevance and logic solution approach. Data was analyzed using logic solution model. Findings from the study revealed that the investigative accounting skills of the forensic accountant empower him to address the problem of financial and any other crimes. The study concluded that the forensic accountant should adopt the inference, relevance and logic solution approach (IRLS) in dealing with financial crimes in corporate organization in Nigeria.

Evans (2017) examined forensic accounting and the combating of economic and financial crimes in Ghana. The study employed a survey research design by sampling all the technical officers of economic and organized crime office of Ghana. The data was analyzed using a Regression Model. Findings from the study revealed that, the application of forensic accounting technique has significant impact on the combating of economic and financial crimes in Ghana. The study concluded that all institutions (anti-corruption agencies and companies) should establish forensic accounting unit to help strengthen internal controls and ensure thorough investigation in order to prevent, deter and detect financial and economic crimes. Moreover, the study recommended that the board of Ghanaian government should ensure that forensic accounting courses are included in the academic and professional curricula of Ghana Universities and professional institutions to ensure the training and increase the awareness of forensic accounting in Ghana. From the above reviewed literatures, the studies of Izedonmi et al. (2012), Evans (2017) and a host of others on the application of forensic accounting for financial crimes prevention and detection produced different results. These research works did not consider whether the use of forensic accounting techniques can help fight financial crimes. But this study examined the impact of forensic accounting techniques for curbing financial crimes. 


\section{Research Methodology}

This study used survey research design to examine the relevance of forensic accounting techniques in the combating of economic and financial crimes in Nigerian public sector. The population of the study is made up of the entire staffs of the three selected Ministries namely: Ministries of Finance, Ministry of Commerce, Cooperative and Industry and Ministry of Budget and Economic Planning in Osun State, Nigeria. A sample size of sixty six was selected using a purposive sampling technique. This study collected both primary and secondary. The primary data was obtained with the help of research questionnaire distributed to the three selected Ministries. Out of the total numbers of 100 copies of questionnaire distributed, only eighty six (86) of them were returned and considered valid for the purpose of this research work. The structured questionnaire items were designed based on the research objective. Consequently, a 4-point Likert scale consisting of strongly agreed (SA) agreed (A), disagreed (D) and strongly disagreed $(S D)$ was used to solicit the opinion of respondents. The data collected was analyzed using descriptive statistics, multiple regression model and correlation analysis. To ensured that the research the validity and reliability of the instrument, the questionnaire was thoroughly checked by the experts in the field of accounting and research to assess it validity and the Cronbach's Alpha reliability method was used to analyze it reliability which give a reliability coefficient of 0.916 . The researcher also personally went to the sampled ministries premises to administer copies of the questionnaire. The copies of the questionnaire were collected personally after their completion.

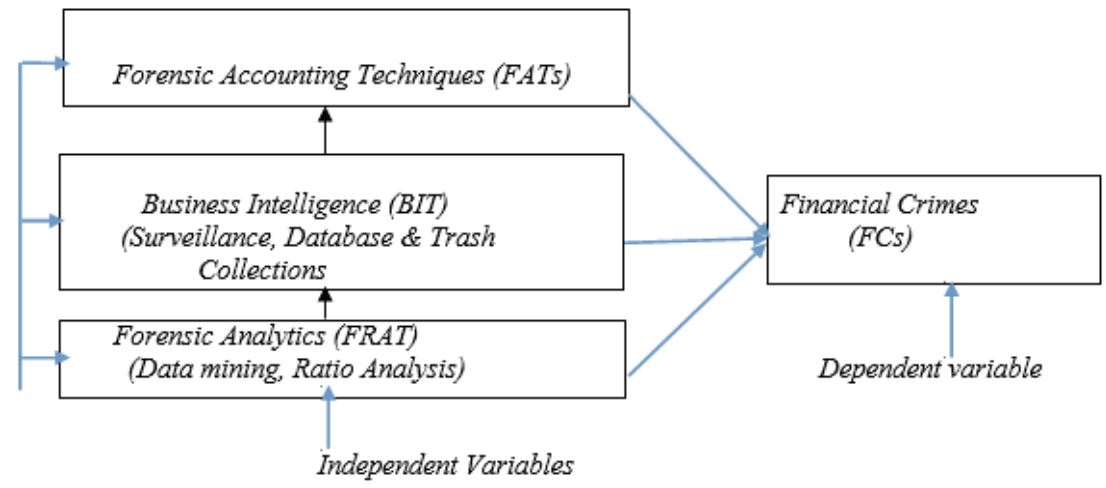

Figure 1.: Conceptual Model of the Study

Source: Author's Compilation (2020)

The above conceptual model in "fig. 1" was developed to show the relationship between the independent variable (Forensic accounting techniques) (FATs) and the dependent variable (Combating financial crimes) (CFCs) as disclosed in figure 1.1 above. The independent variables of forensic accounting techniques are made up of four predictable variable of business intelligence (BIT) and forensic analytics (FRAT). Thus, the model gives the snapshot of techniques that should be employed in the combating of financial crimes (FCs). However, this research did not cover all the variables in the model for combating FCs but a portion.

\subsection{Model Specification and Identification of Variables}

This study employed regression model of forensic accounting services and fraudulence practices adopted by Anuolam et al. (2016) as follow:

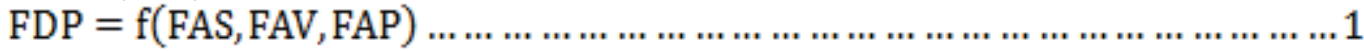

$$
\begin{aligned}
& F D P=f\left(\alpha_{0}+\beta_{1} \text { FAS }+\beta_{2}\right. \text { FAV }
\end{aligned}
$$

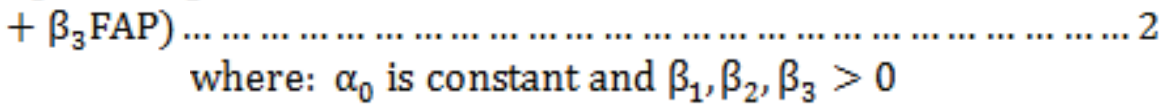

The dependent variable of fraudulent practices (FDP) was used as a function of the three components of independent variables of FAS (Forensic Accounting Services), FAV (Forensic Accounting Validation) and FAP (Forensic Accounting Practices). This study therefore replaced the variables used by Anuolam et al. (2016) with a dependable variable of Combating financial crimes (CFCs) as a function of two predictable variables namely business intelligence (BIT) and forensic analytics (FRAT) to form the specific objectives and research hypotheses in order to capture the relevance of forensic accounting techniques for combating financial crimes in Nigerian public sector. The model is as follow:

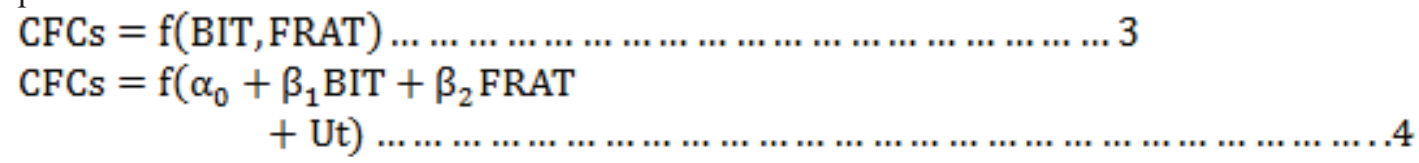

where: $\alpha_{0}$ is constant, Ut is error term and $\beta_{1}, \beta_{2}>0$ 


\subsection{A Priori expectation}

The predictor variable of business intelligence (BIT) and forensic analytics (FRAT) in the specified model are expected to be positively signed. This is expressed mathematical below:

$\beta_{1}, \beta_{2}>0$

\section{Data Presentation, Analysis}

Table 1: Cross-tabulation of Demography of Respondents

\begin{tabular}{|c|c|c|c|c|}
\hline & \multicolumn{3}{|c|}{ Three selected Ministries } & \multirow[t]{2}{*}{ Total } \\
\hline & $\begin{array}{l}\text { Ministry of } \\
\text { Finance }\end{array}$ & $\begin{array}{l}\text { Ministry of Budget \& } \\
\text { Economic Planning }\end{array}$ & $\begin{array}{l}\text { Ministry of Commerce, } \\
\text { Cooperative \& Industry }\end{array}$ & \\
\hline $\begin{array}{lc}\text { Job status } & \text { of Accountants } \\
\text { respondents } & \text { Auditors } \\
\text { Total } & \end{array}$ & $\begin{array}{l}20 \\
18 \\
38\end{array}$ & $\begin{array}{l}14 \\
11 \\
25\end{array}$ & $\begin{array}{l}13 \\
10 \\
23\end{array}$ & $\begin{array}{l}47 \\
39 \\
86\end{array}$ \\
\hline
\end{tabular}

Source: Author's Computation (2020)

The total numbers of 86 questionnaires were distributed to the Accountants and Auditors of the three selected Ministries comprising the sample of 55.8\% staffs from the Ministries of Finance, $22.1 \%$ from the Ministries of Budget and Economic Planning and 22.1\% from the Ministry of Commerce, Cooperative and Industry.

\section{Table.2: Test of Reliability Statistics}

\begin{tabular}{|l|l|}
\hline Cronbach's Alpha & N of Items \\
\hline 0.916 & 3 \\
\hline
\end{tabular}

Source: Author's Computation (2020)

Table 2 above showed Cronbach's Alpha coefficient of 0.972 which above the value of Cronbach's Alpha coefficient recommended by George and Mallery (2003) that the statistical reliability value is expected be 0.70 or above. This indicates that the questionnaire is reliable.

Table 3: Regression Model Summary

\begin{tabular}{|l|l|l|l|l|}
\hline Model & R & R Square & Adjusted R Square & Std. Error of the Estimate \\
\hline 1 & $0.741^{\mathrm{a}}$ & 0.549 & 0.538 & 0.72390 \\
\hline
\end{tabular}

Source: Author's Computation, 2020)

a. Predictors: (Constant), Forensic Analytics, Business Intelligence

Table 3 presented the summarized results of multiple regression analysis showing a moderate positive relationship between the predictor independent variables of forensic accounting techniques and the dependent variable of combating financial crimes (FCs) with the correlation coefficient (R) result of 0.741 which is large enough and indicated linear correlation between the observed and mode-predicted values of the dependent variable. From the table, the coefficient of determination $\left(\mathrm{R}^{2}\right)(0.549)$ shows a moderate positive correlation of the studies variables, which indicates that about $54.9 \%$ of variation in the dependent variable (FCs) is explained by the independent variables (FATs) and other $45.1 \%$ is explained by other factors outside the model and the error term.

Table 4: Regression Coefficient of Predictor Variables

\begin{tabular}{|ll|l|l|l|l|l|}
\hline \multirow{2}{*}{ Model } & \multicolumn{2}{l|}{ Un-standardized Coefficients } & Standardized Coefficients & \multirow{2}{*}{ Sig. } \\
\cline { 2 - 5 } & B & Std. Error & Beta & & \\
\hline \multirow{2}{*}{$\begin{array}{l}\text { 1 Constant) } \\
\text { Business intelligence }\end{array}$} & 1.540 & 0.183 & & 8.398 & .001 \\
& Forensic analytics & 0.367 & 0.205 & 0.334 & 0.787 & .000 \\
\hline
\end{tabular}

Source: Author's Computation, 2020)

Dependent Variable: Curbing Financial Crimes. The result from table 4 the results of explanatory variables showed that business intelligence (BIT) where $\mathrm{t}=1.787$, and $\mathrm{p}=0.00<0.01$ and forensic analytics where $\mathrm{t}=$ 2.263 , and $\mathrm{p}=0.00<0.01$ all have significant positive impact on combating financial crimes in Nigerian public sector. Based on the linear equation of the predictor variables coefficients, that is: $\mathrm{Y}=1.540+0.367 \beta_{1}+$ $0.447 \beta_{2}+\mathrm{Ut}$. This equation depicted that combating financial crimes through the application of forensic accounting techniques in the Nigerian public sector is possible given a unit increase in each of the forensic accounting techniques (Predictor variables) of BIT and FRAT.

\section{Discussion of Results}

The coefficient of relationship (R) of 0.741 for the hypotheses at a significant level of 0.01 showed a strong relationship and the coefficient of determination $\left(R^{2}\right)(0.549)$ shows a moderate positive correlation of the studies variables, which indicates the ability of the regression line to predict dependent variable (FCs) is about $54.9 \%$. The other $45.1 \%$ is explained by other factors outside the model and the error term. The p-value of $0.00<0.01$, thus, null hypothesis is rejected and alternative hypotheses accepted. That is, financial crimes can be combated 
through the application of forensic accounting techniques of BIT and FRAT in the Nigerian public sector. The regression line of FCS $=1.540+0.367 \beta_{1}+0.447 \beta_{2}+\mathrm{Ut}$ also indicated that financial crimes could be combated in the Nigerian public sector given a unit increase in the application of forensic accounting techniques. The results of this study is consistent with the research results of Modugu etal (2013) which indicated that the use of forensic accounting techniques could control financial fraud, financial reporting, and internal control quality and that of Anuolam et al. (2014) who discovered that forensic accounting techniques have positive potential in tackling economic and financial crimes. These results were also in line with study conducted by Okoye et at. (2013) that the application of forensic accounting techniques will significantly reduce the occurrence of fraud cases in the public sector in Nigeria.

\section{Conclusion and Recommendations}

Since the research results have revealed that, forensic accountings can play a significant role in combating financial crimes in Nigeria, it flows that the policy makers can rely on this finding and formulate policies relating to the combating of financial crimes. Consequently, the accounting professional bodies can take a clue to ensure that accountants are trained to use these techniques. More so, ministries in Nigeria can take the findings as a reference point to establish forensic accounting units in their internal audit departments to strengthen their internal controls, and ensure a thorough investigation of financial crimes. Meanwhile, anti-corruption and law enforcement agencies should train personnel to use forensic accounting techniques that will uncover the truth to ensure easy prosecution of financial crimes. This will help prevent financial crimes cases that may be thrown out of court for lack of sufficient evidence in Nigeria. However, the use of forensic accounting techniques can help provide enough evidence for easy judgment. As a result, government of Nigeria should increase the interest in and facilitate the growth of forensic accounting by giving legal backing for proper monitory and investigation of alleged cases of financial crimes. Establishing that forensic accounting techniques are relevant to combating of financial crimes in Nigeria, forensic accounting courses should be included in the academic curricula of Nigerian Universities to train and increase the awareness of forensic accounting in Nigeria. And finally, the professional bodies in Nigeria should including forensic accounting training in their Mandatory Continuous Education Programmes (MCEP) at a reduced cost.

\section{Declaratin}

We, the aforementioned declare that the article sent for publication in your journal has not been published or submitted for printing at any other publisher. The content of the article does not infringe the copyright, legal or material interest of other persons.

We declare that we have written the article independently.

\section{Disclosure statement}

No potential conflict of interest was reported by the authors. We also give my consent for publishing the article on the Publisher's website and any other institutional repository.

Mr. Azeez Ayoola. OLAOYE

Prof. G. K. Akinleye

\section{Acknowledgment}

We the aforementioned wish to thank and appreciate the effort of Dr F. O. Olaoye and Dr. C. O. Olaoye of Accounting Department, Ekiti State University, Ado-Ekiti, Nigeria.

\section{REFERENCES}

Abuh, A. P. \& Acho, Y. (2018), Forensic accounting and economic stability in the Nigeria public sector: The role of economic and financial crime commission. International Journal of Public Administration and management research 4(3) pp of 19- 74.

Adeniyi, A A. (2016), Forensic auditing and financial fraud in Nigerian Deposit Money Banks. European Journal of Accounting, Auditing and Finance Research, 4(8), 1-19.

Aduwo, O. O. (2016), The role of forensic accounting in combating the menace of corporate failure, International Journal of Economic, Commerce and Management, 3(1), Pp.1-15.

Akepe, U. E. (2015), Fighting white collar crimes using forensic investigation skills to enhance operational efficiency: Cameroon as a case study, Africa Director. International Institute of Certified Forensic Investigation professionals inc., USA. www.iicfip.org.

Akenbor, C. O. \& Ironkwe, U. (2014), Forensic auditing techniques and fraudulent practices of public institutions in Nigeria. Journal of Modern Accounting and Auditing, 10(4). 451- 459.

Ameka, C. C \& Ikhatua, O. J. (2016), Forensic accounting and fraud detection in Nigerian public sector. Igbinedion 
University's Journal of Accounting, 12, Pp148-173.

Anuolam, O. M., Onyema, T. E. and Ekeke, U. (2016), Forensic accounting and financial crimes: Adopting the inference, relevance and logic solution approach. West African Journal of Industry and Academic Research, 17, Pp.126-132.

Benjamin, C. O. (2012), Combating fraud and white collar crimes: Lessons from Nigeria. A conference paper presented at $2^{\text {nd }}$ Annual Fraud \& Corruption Africa Summit, Held at Zanzibar Beach Resort, Zanzibar Republic of Tanzania. 1-23.

Dada, S. O., Enyi, P. E., \& Owolabi, S. A. (2013), Forensic accounting: A relevant tool for effective investigation of bribery cases in Nigeria. Unique Journal of Business Management Research, 1(5), 96-99.

Dickson, M., Ogijo, Y. \& Samuel, F. (2013), The role of forensic accountants in fraud detection and national security in Nigeria, Journal of Accounting, Auditing and Taxation, 17,

Evans, O. N. D. (2017), Forensic accounting and the combating of economic and financial crime in Ghana. European Scientific Journal, 13(31), Pp 1-15.

Ehiogbiren, E. E. \& Atu, O. O. K. (2016), Forensic accounting and fraud management: Evidence from Nigeria. Igbineclion University Journal of Accounting, 2, pp 245-283.

Egbunike, F. C. \& Amakor, C. I. (2013), Fraud and Auditors analytical procedure: A test of Benford's Law. E. B. S. Journal of Management Science, 3(1), 14-31.

Eze, E. \& Okoye, E. I. (2019), Forensic accounting and fraud detection and prevention in Imo State public sector. International Journal of Accounting and Taxation, (1), 12-26.

Ezejiofor, R.A., Nwakoby,N. P. \& okoye, F. N. (2016), Impact of forensic accounting on combating fraud in Nigeria banking industry. International Journal of Academic Research in Management and Business, 1(2), $1-19$.

Faboyede, O. S., Makoro, O. D. \& Ben-Caleb, E. (2013), Toward achieving MDGS in Africa; The role of the Institute of Forensic Accountants in Nigeria in eradicating corruption. Journal of Humanities and Social Science, 13(3), 30-34.

Glenn, D. \& Matthew, D. G. (2004), Criminal thinking and identity in male white collar offenders. Federal Correlation Institution, Schuylkill, Pennsyivania. 263-281.

George, D. \& Mallery, P. (2003), SPSS for Windows step by step: A simple guide and reference. 11.0 update. Boston: Allyn \& Bacon.

Gbegi, D. 0, \& Adebisi ,.E (2013), The new fraud diamond and-How can it help forensic accountant in fraud investigation in Nigeria? European Journal of Accounting, Auditing and Finance Research, 1(4), 129-138.

Gbegi, D.0, \& Habila, E. (2017), Effect of forensic accounting evidence on litigation services in the Nigerian judicial system. Nigeria Journal of Management Sciences, 6(1), 104-113

Ibrahim, J., Adeyemi, M. A. \& Odunayo, K. H. (2015), Implication of financial crimes and corruption on manufacturing firms in Osun State, Nigeria. European Journal of Business and Management, 7(12), 102-109.

Ibrahim, U., Rose S. B., \& Mohammed, M, B, (2016), Adoption of forensic accounting in fraud detection process by anti-corruption agency: A conceptual framework. International Journal of Management and Review, 6(5), 139-148.

Igweonyia, O. V. (2016), Forensic accounting as a panacea to alleviation of fraudulent practices in Nigerian Public sector organizations (A study of some selected Ministries in Enugu State. International Journal of Management and Applied Science, 2(9), 8-158.

Ifeaniyi, M. \& Joseph, M. O. (2013), Forensic accounting: A relief to corporate fraud. Research Journal of Finance and Accounting, 4(14), 43-50.

Ile, C. M. \& Odimmega, C.G. (2018), Use of forensic accounting techniques in the, detection of fraud in tertiary institutions in Anambra State. Nigeria. International Multi-disciplinary Journal, 12(1), 66-76.

Ijeoma, F. (2015), Empirical analysis on the use of forensic accounting techniques in curbing creative accounting. International Journal of Economic, Commerce and Management, 3(1), 1-15.

Ifath, S., Pranathi, Asra, S. \& Amathun, N. (2014), Forensic accounting and fraud examination in India. International Journal of Innovative Research and Development, 13(12), 171-177.

Izedonmi, F. \& Ibadin P. O. (2012), Forensic Accounting and Financial Crimes: Adopting the Inference, Relevance and Logic Solution Approach. African Research Review, An International Multidisciplinary Journal, Ethiopia, 6 (4), 125-139.

Jacqui-Lyn, M., Constant, V. G., Jan, V. R. \& Albert, V. Z (2014), Conceptualizing the South African Forensic Accountant. Journal of Forensic \& Investigative Accounting, 6(3), 98- 153.

Jephitha, K. K.., Gillian, M. \& George K. (2019), Forensic accounting skills and fraud control in country governments in Kena Region. International Journal of Economics, Commerce and Management, 7(6), 32434.

Joseph, F. A., Okike, B. M. \& Yoko, V. E. (2016), The impact of forensic accounting in fraud detection and prevention: Evidence from Nigerian public sector. International Journal of Business Marketing and 
Management, 34-41.

Karen, A. M. (2003), Increasing firm value through detection and prevention of white collar crime. Strategic Management Journal, 24, 587-614.

Lawan, Y., Magaji, A. \& Naziru. S. (2018), Influence of forensic accounting practices on fraud prevention among listed companies in Nigeria. Journal of Accounting, Auditing and Taxation, 2(1), 18-24.

Manas, C. (2014), Problems and prospects of forensic accounting profession in India. International Journal of Informative \& Futuristic Research 2(1), 1-9.

Mohammed, U. B. \& Peter, K. N. (2016), Immunity clause and white collar crimes in Nigeria; A call for the withdrawal of immunity clause. Journal of Research in Humanities and Social Science, 4(9), 60-65.

Nenyiaba, I. C., Osisioma, B. C \& Okoye, E. I. (2015), Combating fraud and white collar crimes in Nigeria through application of international accounting reporting standards. International Journal of economic Development Research and Investment, 6(1), 72-83.

Naziru, S. \& Aidi, A. (2018), Mitigation corruption using forensic accounting investigation techniques: The watchdog perspectives. Indian-Pacific Journal of Accounting and Finance, 2(1), 4-25.

Ogiriki, T. \& Appah, E.(2018), Forensic accounting \& auditing techniques on public sector fraud in Nigeria. International Journal of African and Asian Studies, 27, Pp. 7-16.

Okoye, E. I., \& Gbegi, D. O. (2013), Forensic Accounting: A Tool for Fraud Detection and Prevention in the Public Sector. International Journal of Academic Research in Business and Social Sciences, 3(3), 2222-6990

Okoye, 1. Adeniyi, S.I, \& Obidi, U. E. (2019), Forensic Accounting and financial fraud dissection through interview process in selected Federal Ministries Enugu State. International Journal of Recent Innovation in Academic Research 3(12), 88-104.

Okoye, E. I., Adeniyi, S.T \& James O N (2019), Effect of forensic accounting on fraud management in selected firms in Nigeria. International Journal of Economic, Business and Management Research, 3(12), 149168.

Olaoye, C. O., Ogundipe, A. A. \& Dada, R. A. (2019), Formal education and forensic accounting development in Nigeria. ACTA Universitatis Danubius (AUDCE), 15(2), 263-274.

Oyeokun, S. (2017), Forensic accounting investigation techniques: Any rationalization? SSRN Electronic Journal, 2(3), 1-17.

Ozili, P. K. (2016), Forensic accounting and fraud -A review of literature and policy implications. International Journal of accounting and economics studies, 3(1), 63-68.

Rabiu, A. Noorhayati, M. \& Muhammad, S. N. (2015), Fraud triangle and fraud diamond theory: Understanding the convergent and divergent for future research. European Journal of Business and Management, 7(28), 3037.

Raymond, A. E., Nkiru, P. N., Jane, F. N \& Okoye, E. (2016), Impact of forensic accounting on combating fraud in Nigerian banking industry. International Journal of Academic Research in Management and Business, $1(1), 1-29$.

Tim, A. A. \& Sam, A. A. (2016), A criminological profile of white collar crime. The Journal of Applied Business Research, 32, 129-142.

Ugwuja, D. I. (2016), The Economic and Financial Crimes Commission (EFCC) and the fight against corruption in Nigeria. IOSR Journal of Research and Method in Education 6(4), 74-79.

Yucel, F. (2010), Effectiveness of red flags in detecting fraudulent financial reporting: An application in Turkey. The Journal of Accounting and Finance, 139-158. 